\title{
O testemunho teológico comum de Paulo e João: de R. Bultmann aos nossos dias
}

\section{The common theological testimony of Paul and John: from R. Bultmann to our days}

José Otacio Oliveira Guedes

\section{Resumo}

A presente pesquisa se propõe um estudo bibliográfico que contemple alguns dos clássicos comentadores do Evangelho de João (R. Bultmann, C. H. Dodd, R. Brown, C. K. Barrett, R. Schnackenburg). Da análise histórica, passa-se a análise teológica a partir dos tratados da sistemática: criação, antropologia, cristologia, eclesiologia e escatologia. Os frutos da pesquisa são: 1. A verificação da relação de Paulo e João em nível semântico e teológico. Não foram verificados contatos literários; 2 . A constatação de um caminho aberto de pesquisa exegética e teológica quanto à relação de textos de corpora distintos.

Palavras-chave: Kerigma; Teologia de João; Teologia de Paulo.

\section{Abstract}

The present paper proposes a bibliographical study that contemplates the same classic commentators of the Gospel of John (R. Bultmann, C. H. Dodd, R. Brown, C. K. Barrett, R. Schnackenburg). From the historical analysis, it passes to the theological analysis from the treaties of the systematic: creation, anthropology, Christology, ecclesiology and eschatology. The fruits of the 
search are: 1. The examination of the relation between Paul and John in semantic level and theological. Literary contacts were not checked; 2 . The verification of an open path of exegetical and theological search as to the relation among texts of different corpora.

Keywords: Kerigma, John's theology, Paul's theology.

\section{Introdução}

Dado o pressuposto teológico de unidade do cânon, a presente pesquisa pretende passar em revista parte da história da produção bíblico-teológica para verificar a densidade do que foi produzido e analisar a viabilidade de se repropor ao ambiente acadêmico o estudo de relação de textos de corpora diferentes, em uma leitura que, sem perder o rigor metodológico, interesse-se em nutrir a comunidade de fé.

O presente estudo é bibliográfico. O resultado pretende apresentar um caminho para ulteriores pesquisas no âmbito da exegese, que leve em conta o pressuposto teológico da unidade do cânon. Há veios teológicos comuns que poderão ser melhor evidenciados com estudos comparativos ${ }^{1}$.

O resultado da pesquisa será apresentado em dois pontos: 1. A análise dos autores que tratam da relação de Paulo e João: R. Bultmann, C. H. Dodd, R. Brown, C. K. Barrett, R. Schnackenburg; 2. Organizar o material pesquisado da relação de Paulo e João a partir dos tratados da teologia sistemática: criação, antropologia, cristologia, eclesiologia e escatologia.

A relação teológica e semântica de Paulo com João só é estudada nos comentários sobre o Quarto Evangelho (EvJo) ou em estudos de pontos específicos de contato entre os dois corpora. Isso se explica pelo fato do EvJo ser posterior às cartas de Paulo, não tendo assim que verificar dependência de

\footnotetext{
${ }^{1}$ A relação de textos de corpora diferentes é uma abordagem que pode e deve ser feita, sem com isso voltar a um estágio que não leve em conta a contribuição do método histórico-crítico. Paul Ricoeur relacionou Paulo e os Sinóticos: "Façamos algumas proposições nessa direção. Não haveria uma convergência de significação entre a vinda da 'justiça de Deus' sem a lei na doutrina de Paulo, e a vinda proclamada em parábolas [...], por exemplo, na parábola da pérola e, de maneira mais explícita, na parábola do grande banquete [...]? E, por contraste, a tentativa mortal de se obter justiça pela lei não encontra sua contraparte nas parábolas 'trágicas'? Do mesmo modo, a 'liberdade que a justiça dá' não está descrita nas parábolas de conversão e de decisão?” (RICOEUR, P. A Hermenêutica Bíblica, p. 215). A relação entre o EvJo e os sinóticos é mais comum. (Cf. SCHNACKENBURG, R. El Evangelio Según San Juan (vol. I), pp. 53-76).
} 
Paulo em relação a João. Disto resulta que a pesquisa sobre a relação de Paulo e João considerará os comentários sobre o EvJo e sobre estudos de aspectos pontuais desta relação.

\section{Relação de Paulo e João nos teólogos bíblicos: de Bultmann aos nossos dias}

O carro-chefe da pesquisa da relação de Paulo com João são os estudos de Bultmann, sendo quem mais se interessou pela novidade da teologia neotestamentária apresentada pelos dois corpora conjuntamente. Esse autor dedica praticamente toda sua obra sobre o NT para tratar da teologia de Paulo e de João ${ }^{2}$. Para ele, "o querigma cristão tem seu parâmetro em Paulo e João, em comparação com os quais o 'resto' do Novo Testamento quase se torna "secundário"”’.

Bultmann deu novo enquadramento a várias questões do Novo Testamento ${ }^{4}$. Se é verdade que não conseguiu unanimidade para todas as ques-

${ }^{2}$ Cf. BULTMANN, R. Teologia do Novo Testamento (1948-1953). Esta obra contém três partes: I. Premissas e motivos da teologia neotestamentária; II. A teologia de Paulo e de João; III. O desenvolvimento até a Igreja Antiga. A I e a II partes são, respectivamente, "premissas" e "desenvolvimento" da teologia paulina e joanina, em última análise. Fazendo eco da concepção bultmanniana, Millas afirma: "Paulo - e João - teriam superado o perigo corrigindo radicalmente a influência das correntes de pensamento contemporâneas [judaísmo, gnose e religiões mistéricas], chegando a uma reflexão teológica que teria afirmado decisivamente a identidade do cristianismo nascente" (MILLAS, J.M. La concepción Paulina de la fe y la existencia cristiana según la interpretación de Rudolf Bultmann, p. 193).

${ }^{3}$ BRAKEMEIER, G., Apresentação à edição Brasileira da Teologia do Novo Testamento, de Rudolf Bultmann, p. 27. Este destaque dado a Paulo e João fica notório na estrutura desta obra de Bultmann, na qual a I PARTE é: Premissas e motivos da teologia neotestamentária; a II PARTE: A teologia de Paulo e João; e a III PARTE: O desenvolvimento até a Igreja Antiga. Vê-se que teologia propriamente dita no Novo Testamento é a desenvolvida por Paulo e João.

${ }^{4}$ Especificamente quanto ao EvJo - a primeira edição do comentário de Bultmann sobre o Evangelho de João é de 1941: Das Evangelium des Johannes. Göttingen: Vandenhoed \& Ruprecht, 1952 -, Bultmann toma posição sobre três questões principalmente: a) a utilização das fontes: 1 . Fonte dos sinais (semeia-Quelle); 2. Fonte de sabor gnóstico nos discursos de revelação (Offenbarungsreden); 3. Fonte para a paixão e ressurreição. A hipótese de Bultmann das fontes praticamente não subsiste diante da evidência de elementos redacionais que verificam a unidade literária e teológica do EvJo: "1) O Quarto Evangelho é uma obra perfeitamente unitária, que o autor construiu sobre um plano bem definido ao qual conferiu um espírito unitário. 2) O Evangelho constitui, assim, uma unidade estilística extraordinariamente trabalhada que, de fato, marca o joanismo em todas as partes" (BLANK, J. El Evangelio según San Juan, p. 21). Se existem fontes, a redação como encontramos não nos permite ter acesso a elas. b) a pluralidade de etapas redacionais: três etapas: as fontes; o evangelista; "um autor eclesiástico", dando-lhe uma orientação 
tões levantadas por ele, é também verdade que ele não pode ser ignorado em nenhuma delas, dada a profundidade e originalidade de seus estudos. $\mathrm{Na}$ relação específica de Paulo com João são dele as reflexões que instigaram esta pesquisa.

Bultmann é fortemente influenciado pela filosofia existencialista de Martin Heidegger, Sören Kierkegaard e pelo estudo da história das religiões ${ }^{5}$. Isso deixou marcas em seu entendimento do NT. A relevância do querigma cristão está, para ele, em propor uma decisão para uma existência autêntica. $\mathrm{O}$ seu estudo do NT é contextualizado na relação com o ambiente religioso e cultural do período neotestamentário. Para entender a contribuição de Bultmann, deve-se ter presente seu pressuposto de que as novas percepções da vida, mesmo a religiosa, estão sempre ligadas a um feixe de relações. Donde o cristianismo ter a ver com as religiões mistéricas, com o mito gnóstico, com o ambiente helenista de modo geral ${ }^{6}$.

Para Bultmann, o que é normativo na Escritura é o querigma. Paulo e João elaboram interpretações do querigma, interpretações demitizantes ${ }^{7}$. O processo, porém, não está acabado, é mesmo necessário continuá-lo, libertando a fé e todo seu potencial de chamar as pessoas a uma decisão

mais "ortodoxa" ao evangelho que resultava difícil de ser assimilado eclesialmente. Esta figura do "redator eclesiástico" de Bultmann encontra ressonância na figura do "Jean III" de Boismard (cf. BOISMARD, M.-E - LAMOUILLE, A. L'Évangile de Jean. Commentaire. Paris: Cerf, 1977). c) a independência a respeito dos sinóticos: o tema da dependência (com as mais variadas teorias) perdurou até Bultmann, dado como pressuposto: João conhece e depende dos Sinóticos. Com ele começa uma nova onda de defensores da independência. O mistério da relação de João com a tradição Sinótica pode sempre continuar a dividir os pesquisadores, duas coisas, porém são certas: existe uma relação e ela é misteriosa. Cf. GOURGUES, M. Cinquante ans de recherche johannique. De Bultmann à la narratologie, pp. 230-2.

${ }^{5} \mathrm{O}$ estudo da história das religiões será influenciado por diversos ramos do saber: pelas abordagens psicológica (Sigmund Freud, Carl Gustav Jung, Karol Kérény, Melanie Klein), fenomenológica (Rudolf Otto, Mircea Eliade), ou a figura da mitologia comparativa (Joseph Campbell, Georges Dumézil) ou em antropologia social (Claude Lévi-Strauss). Esses, por sua vez, irão influenciar Bultmann.

${ }^{6}$ Cf. BULTMANN, R. A Cristologia do Novo Testamento. In: Crer e Compreender, pp. 109-10. 7 "Sob demitologização entendo um procedimento hermenêutico que interroga enunciados ou textos mitológicos quanto a seu teor de realidade" (Id. O problema da demitologização. In: Demitologização. Coletânea de ensaios, p. 95). Alhures diz: "Pode-se dizer que os mitos dão à realidade transcendente uma objetividade imanente a este mundo. Eles atribuem uma objetividade mundana àquilo que é não-mundano" (Id. Jesus. Mythologie et démytologisation, Paris. Du Seuil, 1968, p. 193). Bultmann não propõe a remoção da linguagem mítica, mas a reinterpretação para torná-la significativa. 
para a autenticidade de sua existência, levando em conta a visão de mundo (Weltanschauung) própria de uma época ${ }^{8}$.

Ao tratar do quadro histórico da teologia de João, Bultmann mostrou como ele vê a relação deste com Paulo. Eis o pressuposto do autor:

A relação entre João e Paulo, porém, não pode ser entendida segundo o esquema de um desenvolvimento monolinear da teologia protocristã, pois ambos vão a direções totalmente diferentes. Como João se encontra a certa distância da comunidade primitiva, ele deverá ser mais recente do que Paulo; mas João não pressupõe a este como elo intermediário entre si e a comunidade primitiva. A literatura deuteropaulina, o modo como desenvolveu o paulinismo, ilustra-o (Colossenses, Efésios, 2Tessalonissenses, Pastorais, 1Pedro) - este é um mundo diferente do de João?.

Afirma que o cristianismo não se desenvolveu como uma "grandeza uniforme". Pode-se falar de variadas formulações do cristianismo. Como pré-paulina, admite a existência de uma percepção ainda nos limites do judaísmo palestino, que seria o querigma da comunidade primitiva, e outra já em comunidades de cristãos helenistas. Essas concepções, segundo o autor, mantiveram-se vivas ao lado de Paulo, mesmo com influxos recíprocos.

Encontra-se representação dessas variadas correntes na teologia joanina, porém, sem influência paulina ${ }^{10}$. A dialética de pontos de encontro e desencontro marca o estudo de Bultmann quanto à relação de Paulo e João.

Depois de Bultmann, o tema da relação de Paulo e João voltou de modo, em grande parte, repetitivo com Dodd. Após pontuar a relação do EvJo com os sinóticos, ele fala daquilo em que pode o EvJo assemelhar-se aos escritos paulinos. Dodd indica as fases do estudo do EvJo: de uma inocente tentativa de harmonizar os escritos paulinos e joaninos, passou-se ao criticismo no qual foi destacado o próprio de cada livro e, segundo ele, teria se tornado comum, em um dado momento das pesquisas, superestimar a dependência em relação a Paulo.

\footnotetext{
${ }^{8}$ Eis um clássico texto de Bultmann: "Não se pode utilizar luz elétrica e aparelho de rádio, em casos de doença empregar modernos meios médicos e clínicos e, simultaneamente acreditar no mundo dos espíritos e dos milagres do Novo Testamento. E quem supuser que o pode para sua pessoa, dever-se-á dar conta de que se declará-lo como postura da fé cristã, estará com isso tornando incompreensível e impossível a proclamação cristã no presente" (Id. Novo Testamento e mitologia. In: Crer e Compreender, p. 16).

${ }^{9}$ Id. Teologia do Novo Testamento, p. 433.

${ }^{10}$ Cf. Id. Teologia do Novo Testamento, p. 107.
} 
Dodd admite que "é bem provável que o evangelista não tenha escapado ao poderoso influxo do primeiro grande teólogo cristão", e que poderia ter "preparado o caminho para a comunidade cristã joanina"11, chegando mesmo a influenciar o autor do EvJo. Dodd, porém, não indica em que aspecto teria sido este influxo. Ele acena ao aspecto cristológico, mas somente na relação do EvJo com as deuteropaulinas.

Para Dodd está clara a exclusão de "qualquer conexão literária"12, e mesmo no conjunto da teologia ele afirma que o caminho de Paulo é notavelmente diverso do pensamento joanino. Esta diversidade possui, porém, um veio comum, que é o esforço de reinterpretar o querigma. As obras deles (Paulo e João) "representam os mais significativos e ousados desenvolvimentos da pregação apostólica no Novo Testamento"13.

Dodd não deixa claro se a relação de João com Paulo se deve somente a um substrato de ideias comuns advindas da corrente judaico-helenista, ou se teria alguma dependência, como parece indicar ao falar do trabalho missionário de Paulo em Éfeso. Esta falta de clareza se deve realmente ao que ele afirma do autor do EvJo como tendo uma "inteligência poderosa e independente". Ou seja, mesmo se houvesse alguma dependência, esta teria sido domesticada pela originalidade do autor do EvJo. Isso fez com que todo o material (escrito ou oral) fosse submetido a uma organização conceitual na qual, só com dificuldade, podem ser apontadas fontes distintas. ${ }^{14}$

Charles Barrett destacou pontos de contato entre Paulo e João: teológico, cristológico, antropológico e escatológico. Quando fala dos pontos

${ }^{11}$ DODD, C.H. A Interpretação do Quarto Evangelho, pp. 19.20.

${ }^{12}$ Id. p. 20.

${ }^{13}$ Id. La prédication apostolique et ses développements, p. 95.

${ }^{14}$ Cf. DODD, C.H. A Interpretação do Quarto Evangelho. Nesta obra, Dodd aponta quatro veios de influxo: a) o influxo da literatura hermética: "a maior parte destes escritos são provavelmente mais tardios que o Quarto Evangelho. (...) Mas o tipo de pensamento religioso que eles representam pode ser seguido até um período mais antigo" (p. 23); b) o influxo do judaísmo helenístico: "A figura mais conhecida e representativa do judaísmo helenístico é Fílon de Alexandria" (...)."sempre tem sido reconhecido que o pensamento joanino tem uma espécie de afinidade com o de Fílon" (pp. 77-8); c) o influxo do judaísmo rabínico: "é perfeitamente evidente que está subjacente um idioma semítico. Isto coloca o Evangelho dentro de um contexto judaico, do qual devemos estar conscientes" (p. 104). d) o influxo do gnosticismo: "o gnosticismo pode ser considerado como um movimento religioso, mais antigo que o cristianismo, e originalmente independente dele (...).” Dodd se propõe a "detectar elementos da doutrina gnóstica que possa provir de uma etapa mais primitiva, e pertencem ao clima geral de pensamento religioso no qual viveram o Quarto Evangelista e seus leitores" (pp. 141-2). Nota-se que o autor não fala de nenhum influxo de Paulo, como teria admitido. 
comuns entre Paulo e João, ele não acrescenta novidade ao que já foi dito por Bultmann e Dodd. Assevera que o contato teológico é devido a que ambos estejam ancorados na "primitiva tradição cristã" e que "João não era um deuteropaulinista", no entanto, o autor admite que "a teologia joanina pressupõe a existência da paulina" 15 .

Rudolf Schnackenburg colhe o fruto dos estudos que o precederam. Como os demais autores, seu foco principal é a relação da cristologia de Paulo e de João. Com Schnackenburg a pesquisa chega aos anos 70.

Não obstante a grande valorização dos métodos sincrônicos que se seguiu, nota-se um desinteresse do ambiente acadêmico pela relação teológica dos corpora, particularmente no Novo Testamento, a não ser que houvesse explícita dependência textual; e esse não é o caso do EvJo em relação aos escritos paulinos.

Recentemente, esta relação de Paulo com João, enquanto autores de escritos foi revisitada quanto à origem do Apocalipse ${ }^{16}$. $\mathrm{O}$ autor do artigo que trata desta questão indaga sobre o fato de o Apocalipse de João ter sido escrito na Ásia Menor, e esta região teria sido evangelizada por Paulo. Ele questiona, também, sobre a atitude de João para com o legado recebido do grande missionário dos Gentios.

\section{Relação de Paulo e João: síntese a partir da teologia}

$\mathrm{Na}$ sequência, serão feitas, pontualmente, as relações de Paulo com João. Os limites da exposição estão estabelecidos pelos pontos tratados pelos autores no que tange à relação de Paulo e João. Outros autores, não diretamente interessados nesta relação serão citados tanto quanto esclareçam os pontos tratados pelos próprios autores que estarão no foco da pesquisa. Embora os autores tratados sejam exegetas e não teólogos sistemáticos, para bem dispor a exposição, serão utilizados os tratados sugeridos pela sistemática: criação, antropologia, cristologia, eclesiologia e escatologia. Vale ressaltar que nem todos os autores citados trataram de todos estes pontos quando falam da relação de Paulo com o João.

\footnotetext{
${ }^{15}$ BARRETT, C. K. The Gospel according to John, p. 47.

${ }^{16}$ Cf. MÜLLER-FIEBERG, R. Paulusrezeption der Johannesoffenbarung?, pp. 83-103.
} 


\subsection{Criação}

Tanto para João quanto para Paulo o mundo continua compreensível como criação de Deus. Em ambos, está demitologizado o dualismo gnóstico, e o conceito de Deus contém a paradoxal união de juízo e graça ${ }^{17}$. Este é o pressuposto da reflexão sobre o ser humano e sua colocação no mundo: Deus não faz parte do mundo, nem tampouco ele é o mundo como um todo, ele está, sim, justaposto ao mundo. Não há intenção de caracterizar Deus como causa do mundo, "a intenção é de mostrar que o mundo está qualificado como criação, ele tem o caráter de criação, ou seja, ele não é visto apenas como algo objetivamente existente"18. Tal visão não é própria só de Paulo e de João, visto que todo o Novo Testamento assume as primeiras páginas do Gênesis como pedra angular e dado definitivo: Deus é o criador e as coisas são criaturas ${ }^{19}$.

Paulo vê o tema da criação em relação à justificação. A justificação é uma nova criação, uma "renovação intrínseca do ser" ${ }^{20}$, pois quem está em Cristo

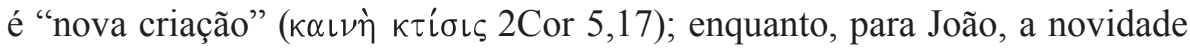
corresponde ao julgamento que se dá: quem escuta a palavra do enviado tem a vida eterna (cf. Jo 5,24). Este é o campo da revelação, do conhecimento ${ }^{21}$.

Paulo depende da categoria "criação" para sua teologia, enquanto que em João predominam a "revelação" e o "conhecimento". Por isso, Paulo destaca a desordem na criação feita pelo pecado, um poder personificado; João, por sua vez, destaca que o pecado é não crer em Jesus, é recusá-lo. Por isso "para João pecado é uma ofensa contra a luz, para Paulo ele é uma desordem intro-

${ }^{17}$ Cf. BULTMANN, R. Teologia do Novo Testamento, pp. 437-8.

${ }^{18}$ Id. A Escatologia do Evangelho de João. In: Crer e Compreender. p. 122.

${ }^{19}$ Mt 6,15-34: Deus é o Pai que cuida dos pássaros e dos lírios do campo; ele faz chover e nascer o sol sobre justos e injustos (cf. Mt 5,45); é em Deus que "vivemos, nos movemos e existimos" (At 17,28); por haver criado todas as coisas, pode submetê-las a Jesus (cf. Hb 2,8); este é o pressuposto para a criação de "um novo céu e uma nova terra" (Ap 21,1).

${ }^{20}$ Cf. BENOIT, P. Paulinisme et Johannisme, p. 202. Esta é a visão católica da justificação. Bultmann não compartilha desta renovação do ser, sendo a justificação uma ação essencialmente forense: "não se refere a nenhuma qualidade da pessoa, e sim designa uma relação" (BULTMANN, R. Teologia do Novo Testamento, p. 335.) e, ainda, "a pessoa é nova na medida em que crê, não por apresentar novas qualidades objetivas (vorfindlich)" (O problema da "Teologia Natural". In: Crer e Compreender. p. 137). Neste sentido a fé não é algo novo, mas é um novo modo de entender-se a si mesmo de uma nova maneira.

${ }^{21}$ Cf. BROWN, J.K. Creation's Renewal in the Gospel of John. CBQ 72, n.2 (2010) 275-290.

É destacada a referência do EvJo com o motivo criacional do Gênesis. 


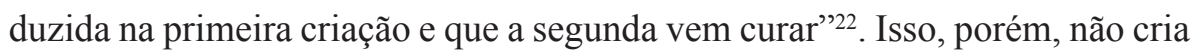
"nenhuma oposição entre estes modos de ver, mas uma complementaridade enriquecedora, e que importa não descuidar as nuanças" "23. A criação é, para Paulo e João, mais um pressuposto teológico do que um teologumenon.

\subsection{Antropologia}

A terminologia antropológica característica de Paulo ( $\sigma \hat{\omega} \mu \alpha, \quad \psi v \chi \eta \dot{\eta}$, $\kappa \alpha \rho \delta i ́ \alpha, \nu 0 u ̂ \varsigma, \nu o ́ \eta \mu \alpha)$, que remonta ao AT, é relativamente rara em João. Mas "a despeito de todas as diferenças no modo de pensar e na terminologia, existe uma profunda afinidade objetiva entre João e Paulo"24. A antropologia cristã se realiza em um modo escatológico de viver. Tanto para Paulo quanto para João, o ser humano só pode ser aquilo que já é. "Justamente por isso, Paulo exorta os crentes a serem santos, por já estarem santificados (1Cor 1,2; 6,11; cf. 5,7). Precisamente por isso, também exorta a andar no Espírito, pois o crente já está no Espírito (Gl 5,25). Por isso, também, exorta a aniquilar o pecado, porque o crente já está morto para o pecado $(\mathrm{Rm} 6,11 \mathrm{ss})$. Ou o dito jo-

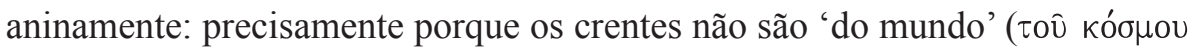
Jo 17,16$)$, podem vencer o mundo" 25 .

Paulo e o João colocam como fundamento da vida cristã a fé. Paulo prioriza o substantivo, João destaca o verbo. Para Paulo, a fé é, antes de tudo, confiar em alguém; para João há um conteúdo a se aderir: Jesus é o Cristo o Filho de Deus (Jo 20,31). O ser humano se determina na decisão que toma perante a proclamação ${ }^{26}$.

O discurso antropológico, com o evento Cristo, ganha um referencial para reflexão: a relação com Cristo. Barrett remarca que uma das mais

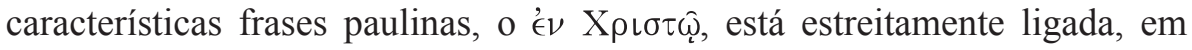
significado, com o "permanecer em" do $\mathrm{EvJo}^{27}$. Porém, "a fé não altera a natureza humana; [...] o justificado não possui novas qualidades verificáveis;

\footnotetext{
${ }^{22}$ BENOIT, P. Paulinisme et Johannisme, p. 201.

${ }^{23}$ Ibid., p. 205.

${ }^{24}$ BULTMANN, R. Teologia do Novo Testamento, p. 437.

${ }^{25}$ Id. Novo Testamento e Mitologia, In Crer e Compreender, p. 33. Alhures, ele diz: "Exteriormente nada mudou para o crente, mas a relação com o mundo é outra: o mundo já não o afeta mais; a fé é a vitória sobre o mundo (1Jo 5,4)" (p. 28).

${ }^{26}$ Cf. BARRETT, C. K. The Gospel according to John, p. 58.

${ }^{27}$ Cf. Id. The Gospel according to John, p. 57.
} 
mas, que o pecador é o [mesmo] justificado"28. Ademais, "a descrença é, por excelência, a disposição fundamental da existência humana, que ela inclusive a constitui como tal' ${ }^{29}$.

O Novo Testamento em geral e Paulo e João, em especial, não conhecem uma antropologia não teológica. O ser humano não é visto em si, mas na sua relação com Deus, assim como Deus e Jesus Cristo são vistos na relação com o ser humano.

Schnackenburg fala da relação com Jesus com certo misticismo, incluindo a categoria de amizade. Esta categoria está explicitamente presente no EvJo

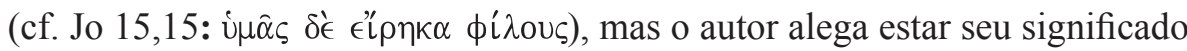
também na teologia paulina.

Quem quiser entender a amizade com Jesus em sua dimensão profunda, deve assimilar um pensamento que aparece tanto em Paulo quanto em João: a amizade com Jesus é uma união interna com o Cristo paciente e ressuscitado e uma adesão ao Espírito Santo que nos é infundido e nos torna filhos de Deus. Paulo sabe que os sofrimentos aceitos por servir a Cristo, o fazem participar existencialmente na sua paixão e morte ${ }^{30}$.

A relação do ser humano com Cristo é tão visceral que, o ser humano sem a fé está sob a ira, ou é mundo sob a ira. A obediência lhe é proposta como alternativa que lhe permite não ser mais do mundo, embora estando no mundo. Exige-se dele abdicar-se de toda segurança que não seja aquela que vem da fé, da vida esperada de Deus.

\subsection{Cristologia}

Neste ponto, interessa o que no NT foi revelado sobre Jesus Cristo e sua obra salvífica. O foco é o que Paulo e João falaram em comum ou em tensão entre si sobre este tema. Aqui a pesquisa não será feita estudando o NT, mas o legado dos autores a partir de Bultmann.

Bultmann pressupõe que "em Paulo e em João, o ensino do Jesus histórico não tem nenhuma ou apenas muito pouca importância" e que "a personalidade de Jesus não tem relevância para o querigma de Paulo nem

\footnotetext{
${ }^{28}$ BULTMANN, R. O problema da “teologia natural”. In: Crer e Compreender, p. 146.

${ }^{29}$ Ibidem.

${ }^{30}$ SCHNACKENBURG, R. Amistad con Jesus, pp. 75-6.
} 
para o de João, aliás, tampouco para o NT de modo geral", e acrescenta: "está claro que, para Paulo, e, de modo ainda mais radical, para João, Jesus, isto é, sua vinda, sua cruz e sua ressurreição ou exaltação, têm o sentido de evento escatológico"31. Nenhum dos dois se interessa pela figura do Jesus histórico, pois "as legendas do nascimento virginal e da ascensão de Jesus encontramos só esporadicamente; Paulo e João não as conhecem"32.

O fato extraordinário do cristianismo, anunciado no querigma, é revestido de uma linguagem mítica: "a cristologia está moldada segundo o mito gnóstico da redenção, tanto em João quanto em Paulo"33. Paulo e João, dão um passo e começam a elaborar demitologização. O que interessa a eles é o anúncio de algo capaz de mudar a percepção da existência. A roupagem histórica do querigma é de tudo secundária nestes escritos neotestamentários. A pergunta "quem foi Jesus", não interessa, não é relevante. A questão pertinente é qual a exigência do querigma para a vida do interlocutor; não a "historie" (fatos acontecidos), mas a "geschichte" (eventos significativos existencialmente) ${ }^{34}$.

${ }^{31}$ BULTMANN, R. Teologia do Novo Testamento, pp. 76-8. Em outro lugar, Bultmann afirma: "Diretamente, Paulo de forma alguma está determinado pelo Jesus histórico" e ainda "o acesso

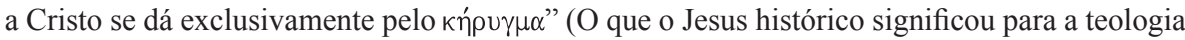
de Paulo. In: Crer e Compreender, pp. 81-101).

${ }^{32}$ BULTMANN, R. Novo Testamento e mitologia. In: Crer e Compreender, p. 19. SCHNACKENBURG, R. Cristologia do Novo Testamento. In: Misterium salutis, p. 89 vê, ao menos em Paulo, que a raiz da conceituação da preexistência seria especulação sapiencial judaico-helenista, e até mesmo coloca em guarda a hipotética existência de um uniforme mito gnóstico de redentor. Sobre o que Bultmann chama "legenda", Benoit argumenta que embora a concepção virginal de Jesus apareça tardiamente, ela é de boa fonte, e o que chamam de "criação de um mito", ele prefere chamar a "descoberta de um mistério" (Cf. BENOIT, P. Paulinisme et Joahannisme, p. 195).

${ }^{33}$ BULTMANN, R. Teologia do Novo Testamento, p. 434. Afirma em um artigo: "Não só os mistérios pagãos conhecem a figura do Deus redentor que morre, mas principalmente a mitologia gnóstico-pagã conhece aquela figura da divindade preexistente, e que, obedecendo à vontade do Pai, veste a roupagem deste mundo e toma sobre si a aflição, ódio e perseguição, a fim de abrir para os seus o caminho rumo ao mundo celestial" (Id. A Cristolologia do Novo Testamento. In: Crer e Compreender, p. 105).

${ }^{34} \mathrm{Cf}$. Id. O que o Jesus histórico significou para a teologia de Paulo. In: Crer e Compreender, p. 97. Em outro artigo afirma: "não se deve perguntar pelos fundamentos históricos de sua história, sua morte; o significado de sua história se deriva daquilo que, através dele, Deus pretende me dizer." (Id. Novo Testamento e Mitologia. in: Crer e Compreender, p. 39). Também afirma que "a cristologia não consiste em especulações acerca da essência, mas na proclamação do evento de Cristo, e que contemplar esse evento compreendendo-o não é especulação, mas reflexão sobre si mesmo, sobre a própria existência nova". Neste mesmo artigo diz: "Tanto faz se ele sabia ser o Messias ou não" (Id. A Cristologia do Novo Testamento. In: Crer e Compreender, pp. 116-9). 
Barrett, na procura da gênese da cristologia do Novo Testamento, se atém à sua fonte no Antigo Testamento. Ele não dá nenhum espaço para as polêmicas sobre as fontes do EvJo. Barrett destaca que ambos fundam sua reflexão cristológica no Antigo Testamento, mais precisamente na fé judaica, pois "a

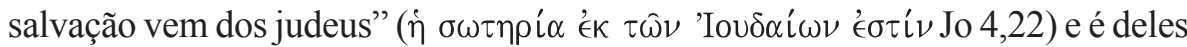

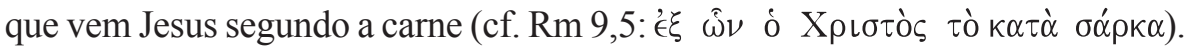
$\mathrm{O}$ messianismo de Jesus está diretamente ligado à esperança de Israel ${ }^{35}$.

Schnackenburg dedica um excursus no seu comentário ao EvJo para tratar da relação de Paulo e João ${ }^{36}$. A afirmação central de sua análise é que vai "Paulo mais na direção de uma theologia crucis e João mais na direção de uma theologia gloriae" ${ }^{37}$. O autor destaca os pontos de encontro e as diferenças, porém sinaliza que "não se deve converter as diferenças em oposição" ${ }^{38}$. Estas duas ideias ele sintetiza afirmando:

Entre a cristologia paulina e a joanina há notáveis diferenças que, certamente não permitem ocultar o querigma subjacente de Cristo crucificado e ressuscitado, que, porém, o modificam, matizam e atualizam com tais diferenças que se impõe uma comparação ${ }^{39}$.

Schnackenburg destaca a justa diferença dos enfoques da theologia crucis paulina e a theologia gloriae joanina. Este é um modo sintético de tratar o assunto. Pois João possui uma clara theologia crucis, embora subordinada à encarnação. A theologia gloriae paulina pressupõe a cruz ${ }^{40}$.

Na relação de Paulo com João, três pontos são destacados pelos autores quanto à cristologia: a) $\mathrm{O}$ preexistente e seu envio; b) $\mathrm{O}$ título de Filho de Deus; c) O querigma do Cristo crucificado e ressuscitado.

${ }^{35}$ Cf. BARRETT, C.K. The Gospel according to John, pp. 54-55.

${ }^{36}$ SCHNACKENBURG, R. La cristología paulina e la cristología joánica. In: El Evangelio según san Juan, $I V$. p. 108-125.

${ }^{37}$ Ibid., p. 114.

${ }^{38}$ Ibid., p. 125.

${ }^{39}$ Ibid., p. 110.

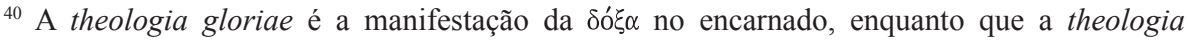
crucis de Paulo seria um Jesus terreno despojado dela. Ora isso é secundário, se pensarmos a compreensão que tem Paulo da $\delta o ́ \xi \alpha$, como "brilho celestial". João também admite que Jesus

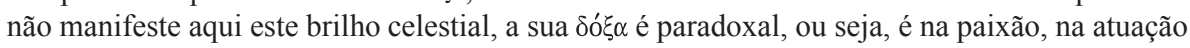
obediente ao Pai que ela se mostra. Neste sentido, também Paulo admite que o Jesus terreno e sua cruz revelam a $\delta o ́ \xi \alpha$ divina (Cf. BULTMANN, R. A Cristologia do Novo Testamento. In: Crer e Compreender, p. 117). 


\section{a) O Preexistente e seu envio}

A descrição feita por Paulo e João do envio do Filho de Deus preexistente em figura humana (F1 2,6-11; Jo 1,14) e do acontecimento salvífico, expressam uma concepção mítica do universo. Essa linguagem mitológica do redentor que desce e sobe como "ente celeste preexistente" traz em si o conteúdo verdadeiro da proclamação neotestamentária, que quer indicar que no "evento Cristo" não se trata de uma pessoa intramundana que está agindo para um destino intramundano, mas ali nos deparamos com a ação do próprio Deus ${ }^{41}$.

Atendo-se à análise dos textos, Schnackenburg constata que o envio do Filho de Deus supõe um contexto histórico-tradicional ${ }^{42}$. A estrutura formal das frases é a mesma: "Deus enviou seu filho para que..." (G1 4,4; Rm 8,3; Jo 3,16s). O envio coloca em foco Deus (não o "Pai") e se expressa mediante os verbos $\dot{\alpha} \pi о \sigma \tau \tau^{\prime} \lambda \lambda \omega$ e $\pi \dot{\epsilon} \mu \pi \omega$ que dificilmente apresentam diferença de significado. Trata-se de um envio ao mundo (explicitamente Jo 3,17, de modo indireto Gl 4,3; Rm $8,2 ; 5,12$ s) e com uma finalidade soteriológica (orações finais com i $\iota \alpha)^{43}$.

É comum a ideia da preexistência em sua aplicação a Jesus Cristo ${ }^{44}$. Segundo Schnackenburg, Paulo teria haurido esta concepção da especulação sapiencial judaica. Para João o conceito da preexistência tem ademais um ambiente apologético frente aos discípulos do Batista (Jo 1,15.30) e frente aos

${ }^{41}$ Cf. BULTMANN, R. A Cristologia do Novo Testamento. In: Crer e Compreender, p. 117; também Novo Testamento e mitologia, p. 13. Schilier afirma que "o mito foi historicizado no NT de tal modo que para sua relação com Jesus Cristo ele foi desfeito enquanto mito. O mito chegou a seu termo, que é, ao mesmo tempo, a sua realização" (Le Nouveau Testament et le Myte. Citado por H. Fries, Démythologisation et vérité théologique. In: Message de Jésus e l'interprétation moderne, p. 201).

${ }^{42}$ Para Paulo, o envio do Filho de Deus se orienta de antemão e em forma plena e total para o acontecimento da cruz, para a morte expiatória e vicária. Para João, a redenção do mundo

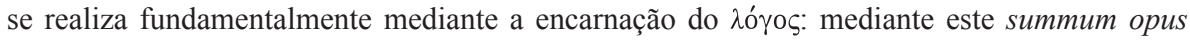
$D e i$, a criação e a imagem do homem são restabelecidas em pureza e santidade originais. De qualquer modo, Schnackenburg, não excluindo a linguagem comum do ambiente helenista em seu contato com o mito do redentor, tal como é proposto por Bultmann, afirma dependência da reflexão sapiencial judaica (Cf. SCHNACKENBURG, R. La cristología paulina e la cristología joánica. In: El Evangelio según san Juan, IV, pp. 118-20).

${ }^{43}$ Ibid., p. 110. Este autor alemão vê como desnecessária referência ao "mito gnóstico do redentor". Ademais, não é comprovada a existência de uma concepção clara deste mito e seu influxo na teologia cristã.

${ }^{44}$ Brown destoa deste pensamento. Ele afirma que: "erroneamente se afirma que Paulo proclamou a mesma espécie de cristologia da preexistência que João"; ele admite que o texto da carta aos Filipenses não se refira à encarnação, mas somente "à vida terrena de Jesus" (BROWN, R. E. $A$ comunidade do discípulo amado, p. 47). 
Fariseus que se diziam filhos de Abraão (Jo 8,58). A preexistência adquire peso notável em toda a cristologia joanina. "Comparada com as passagens paulinas que se ordenam para a ação redentora de Jesus na cruz, a preexistência em João se converte no pressuposto da atividade terrena de Jesus e aponta para a revelação de sua glória sobre a terra e a participação dos crentes na glória celestial do Cristo (Jo 17,24)" "45. Tanto para Paulo quanto para João, o envio do redentor tem o significado de um evento escatológico; ele representa a virada dos tempos (Jo 3,19; 9,39; Gl 4,4).

b) O Filho de Deus

Barrett, como já afirmado, se atém à linguagem e teologia do Antigo Testamento como suficiente para explicar a aproximação de Paulo e João. Para João é mantida a tradição semita do Filho do Homem ${ }^{46}$, enquanto que Paulo opta pela de Homem Celeste e o último Adão (1Cor 15,45-47). ${ }^{47}$

Embora "Filho do homem" não seja o título cristológico predominante nem em Paulo, que é kúpıos, nem no EvJo, que é viós ele exerce, porém, um pólo de unidade. A base comum, na opinião de Schnackenburg, como para Barrett, é a concepção judaico-cristã do Filho de Deus em sentido messiânico. Paulo recolhe a fórmula da constituição do descendente de Davi como Filho de Deus a partir da ressurreição $(\mathrm{Rm} 1,4)$ e João vincula por três vezes o Filho de Deus com uma designação messiânica (Jo 1,49; 11,27; 20,31). O ponto comum é que o Messias é Filho de Deus. Paulo, por sua vez irá enfatizar esse Filho de Deus que se entrega e que é entregue à morte (Gl 2,20; Rm 8,32), enquanto João irá destacar esse Filho de Deus como igual em natureza a Deus (Jo 5,$18 ; 10,33)$.

\footnotetext{
${ }^{45}$ Cf. SCHNACKENBURG, R. La cristología paulina e la cristología joánica. In: El Evangelio según san Juan, $I V$, p. 115. Para Benoit a revelação da preexistência do Cristo, em perspectivas diferentes pelas obras de Paulo e João, tem seu fundamento exclusivamente no AT, quando refletem a relação de Palavra e Espírito, sempre envolvidos na criação e revelação. Segundo nosso autor, o que caracteriza Paulo e João é justamente o enfoque diferenciado: o primeiro enfoca a criação e o segundo a revelação (cf. BENOIT, P. Paulinisme et Johannisme, p. 195). Nesse artigo, Benoit apresenta uma desconfiança em relação às teorias recém-aparecidas no seu tempo das fontes do EvJo.

${ }^{46}$ Jo 1,$51 ; 3,13.14 ; 5,27 ; 6,27 ; 6,53.62 ; 8,28 ; 12,23 ; 12,34$ (2x); 13,31.

${ }^{47}$ Cf. BARRETT, C. K. The Gospel according to John, p. 55.
} 
A partir desse título vê-se também o desenvolvimento independente das cristologias paulinas e joaninas, "Paulo mais da direção de uma theologia crucis e João preferentemente na de uma theologia gloriae" ${ }^{\text {"48. }}$.

\section{c) O querigma do Cristo crucificado e ressuscitado}

Tanto em Paulo quanto no EvJo encontra-se o querigma antiquíssimo do Cristo crucificado e ressuscitado. Entenda-se que na crucificação está a entrega da vida pelos homens e por sua salvação.

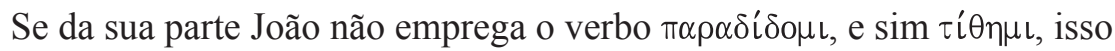
não passa de uma variante de peculiaridades linguísticas. A preposição ưđé $\rho$, importante na ideia de entrega, aparece abundantemente no EvJo ${ }^{49}$. Por outro

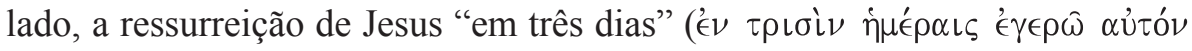
Jo 2,19; cf 2,20) está em tensão com a ideia joanina da exaltação. O Jesus

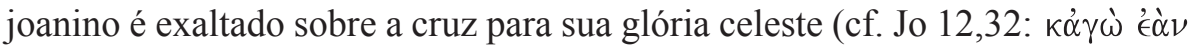

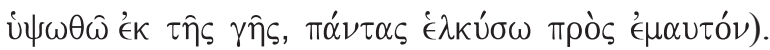

De qualquer modo, vemos João ancorado no primitivo querigma cristão

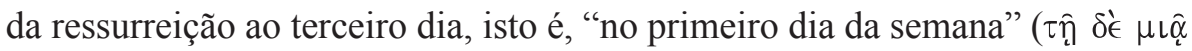

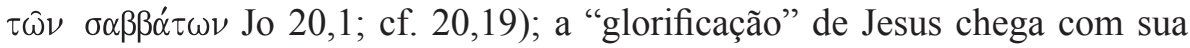
ressurreição, quando então pode comunicar o Espírito (cf. Jo 7,39b; 12,16 com 2,22). "São passagens que, ao menos em seu conjunto, não se pode negá-las ao evangelista para atribuí-las a uma redação, que teria sido a primeira a introduzir a ideia de expiação" 50 .

Os autores destacam contatos e tensões entre Paulo e João quanto à cristologia. Tanto as diferenças quanto os pontos comuns precisam de uma explicação. A pesquisa está aberta, com um veio que pode ser explorado com proveito para a teologia.

${ }^{48}$ SCHNACKENBURG, R. La cristología paulina e la cristología joánica. In: El Evangelio según san Juan, $I V$, p. 117. A palavra da cruz sendo algo incompreensível e absurdo elimina todo orgulho humano (cf. 1Co 1,18.29), o que sustenta a tese fundamental da justificação pela cruz. Para João a cruz é o lugar do dom da vida divina feita pelo cristo exaltado (cf. Jo 3,15). Esta diferença é mostrada sob outra perspectiva por Benoit; enquanto para João "a salvação consiste antes de tudo em renascer para a vida do verdadeiro conhecimento de Deus na luz, enquanto que a salvação paulina reside essencialmente na passagem da morte para a vida por recriação de todo o ser" (BENOIT, P. Paulinisme et Johannisme, p. 200).

${ }^{49}$ Jo 10,11.15b, 15,13; 6,51 "minha carne para a vida do mundo"; 11,50-52 e 18,14 deveria um homem morrer pelo povo; 17,19 "e por eles eu me consagro".

${ }^{50}$ Cf. SCHNACKENBURG, R. La cristología paulina e la cristología joánica. In: El Evangelio según san Juan, $I V$. p. 116. 


\subsection{Eclesiologia}

Neste ponto interessa à pesquisa a novidade comunitária que permaneceu como resultado da ação do Cristo: tanto espiritual quanto institucionalmente, tanto escatológica quanto historicamente.

O que inicialmente se constata é que a terminologia histórico-salvífica

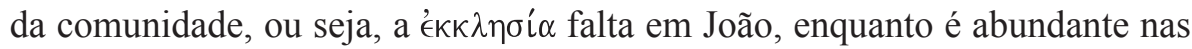

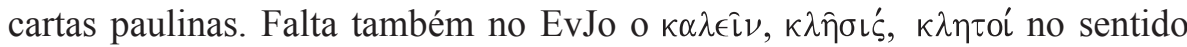
histórico-salvífico. Encontramos em João o '́к $\lambda \dot{\epsilon} \gamma \omega$ (Jo 6,70; 13,18; 15,16)

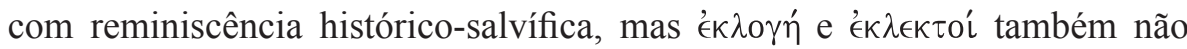
ocorrem em João. Está ausente a designação dos cristãos como ä $\iota_{\llcorner} \iota^{51}$.

Não obstante esse fato de não ser encontrado no EvJo este vocabulário eclesiológico presente no restante do Novo Testamento, nem por isso deixa de haver um verdadeiro discurso eclesiológico no EvJo, sobretudo desenvolvido com as imagens do rebanho (Jo 10) e da videira (Jo 15,1-8); estas imagens têm no Antigo Testamento uma retaguarda que permite passar uma forte reflexão sobre a nova realidade da comunidade dos que creem em $\mathrm{Cristo}^{52}$. A perícope da videira apresenta uma novidade eclesiológica: os ramos não fazem a videira existir, ela os precede; os ramos são videira na videira. Esta mesma intuição eclesiológica segue a reflexão paulina do Corpo de Cristo, na qual o Corpo não é constituído pelos membros, e sim por Cristo; portanto, ele existe antes e além dos membros, não por meio deles e por eles ${ }^{53}$.

Para Bultmann, no evangelho de João - sem os acréscimos do "redator eclesiástico" - não há terminologia eclesiológica e sacramental ${ }^{54}$. Neste caso ficariam como claros acréscimos redacionais as referências ao batismo e à ceia do Senhor (Jo 3,5; 6,51b-58) ${ }^{55}$. Mas, se for considerado o texto final do EvJo, como de resto se deve fazer, é clara a relação dos textos acima com os textos paulinos (Rm 6,1-7; 1Cor 11,17-34).

A expectativa de certa terminologia eclesiológica, fez com que Bultmann não admitisse nenhum discurso eclesiológico em João. Surpreende, porém, sua afirmação que "não existe fé no Cristo que não seja ao mesmo tempo fé na

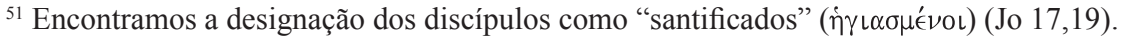

${ }^{52}$ Cf. SCHNACKENBURG, R. La nature et le mystère de l'Église dans le Nouveau Testament, pp. 53-62.

${ }^{53}$ Cf. BULTMANN, R. Teologia do Novo Testamento, p. 379.

${ }^{54}$ Cf. Ibid., p. $436 \mathrm{~s}$.

${ }^{55}$ Ibid., p. 402s.
} 
Igreja como portadora do querigma. Mas a fé na Igreja é ao mesmo tempo a fé no Cristo" ${ }^{56}$. A surpresa é pelo que Bultmann entende por Igreja: realidade escatológica - sem sinais históricos constitutivos - cuja origem se dá pela pregação da palavra. "Para Paulo a ékk $\lambda \eta \sigma i ́ \alpha$ não é em primeiro lugar a reunião cultual, mas uma grandeza histórico-escatológica, o verdadeiro Israel no qual estão reunidas todas as comunidades individuais" ${ }^{57}$.

A imagem da Igreja como "Corpo de Cristo", no seu sentido teológico, deve ser considerada como criação teológica do próprio Paulo, visto que ela não se apresenta em nenhuma outra parte do Novo Testamento. Nesta Igreja cada indivíduo realiza sua condição, o que se define como existência escatológica que não está ligada a este tempo de outra forma que de modo exterior; aliás, a Igreja toda é uma realidade que, em definitivo, não pertence ao mundo, ela é desde já subtraída deste tempo pela ação de Cristo. Desta concepção de Paulo não está excluída a organização da Igreja, na qual o próprio Apóstolo exerce sua autoridade, inclusive sobre o uso dos carismas ${ }^{58}$. Bultmann diz que

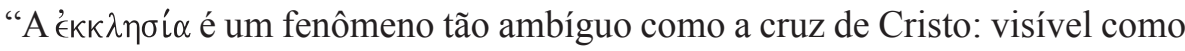
fato no mundo, invisível, porém, simultaneamente visível para o olho da fé, como grandeza do mundo vindouro" 59 .

A metáfora da vinha e dos ramos (Jo 15,1-8) "constitui um paralelo com a ideia paulina do "Corpo de Cristo" ${ }^{60}$. Os contatos de Paulo com João vão além dessas duas imagens. A concepção de Paulo do "Israel de Deus" ('I $\sigma \rho \alpha \grave{\lambda} \lambda$

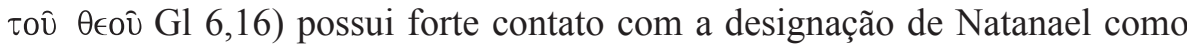

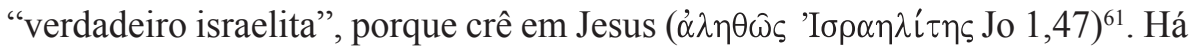
também uma contraparte negativa, de uma anti-Igreja que seria, no EvJo, a "sinagoga" (Jo 9,22; 12,42: não enquanto lugar físico, mas como comunidade de pertença), que teria forte correspondência com a concepção paulina da "Je-

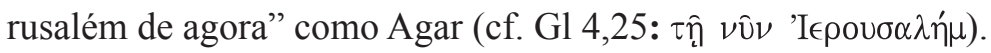

A eclesiologia joanina coloca o destaque na relação pessoal com Jesus, os ramos com a Videira. Esta dimensão é muito cara aos nossos tempos. Ter Jesus como "meu salvador pessoal" se tornou a fonte da espiritualidade. Ao

\footnotetext{
${ }^{56}$ BULTMANN, R. Exegética, 468-469 citado por REFOULÉ, F. Cristologie de Bultmann. In: Que dites-vous du Christ? De Saint Marc à Bonhoeffer, p. 132.

${ }^{57}$ Id. A Cristologia do Novo Testamento. In: Crer e Compreender. p.112.

${ }^{58}$ SCHNACKENBURG, R. La nature et le mystère de l'église dans le Nouveau Testament, pp. 35-7.

${ }^{59}$ BULTMANN, R. Teologia do Novo Testamento, p. 376.

${ }^{60}$ SCHNACKENBURG, R. Op.cit., p. 58.

${ }^{61}$ Cf. BROWN, R.E. Johannine Ecclesiology. The community's origins, p. 382.
} 
lado da eclesiologia paulina do "Corpo de Cristo" (1Cor 12,12-31), com seus vários membros, com carismas e funções diferentes, João marca a identidade do discípulo pela sua relação direta com Jesus Cristo: ramos e videira ${ }^{62}$.

Isto nos leva a concluir os pontos de encontro e tensões entre a percepção paulina do "Corpo" e a joanina da "videira". Concede-se que no pensamento joanino e no paulino haja uma mesma doutrina de fundo, uma coincidência interna que é a essencial dependência de Jesus Cristo. Porém, se distinguem no fato de que a escola joanina o expressa de um modo mais acorde com a tradição bíblica vétero-testamentária (Is 5,1-7; Jr 2,21; Ez 17; Sl 80); Paulo depende mais, neste aspecto, do mundo greco-romano que concebe a sociedade como um corpo vivo. Ademais, encontramos outra distinção que, embora sutil, na prática é importante: a imagem de Paulo sugere um "organismo" mais estruturado, mais "hierarquizado", em certo modo. A escola joanina se centra preferentemente, ainda que não exclusivamente, na "vida" que unifica essencialmente a videira e os ramos, e os ramos entre si. Isto parece indicar que a eclesiologia da escola joanina é uma "eclesiologia da responsabilidade"63.

\subsection{Escatologia}

O cristianismo tem a ver com a resposta ao sentido último da vida e da história. O sentido último é realizado pelo $\tau^{\prime}\left\langle\lambda_{0} \varsigma\right.$, pelo definitivo, pela vida plena dada a partir do juízo e da graça, enfim pela consumação. Este sentido é dado por Jesus Cristo.

O Novo Testamento apresenta claramente duas perspectivas do desfecho da história: de um lado, a escatologia do fim, de cunho apocalíptico e ligado a catástrofes que poriam termo a este mundo, manifestando a $\delta$ ó $\alpha$ de Jesus, que será sua vinda gloriosa no fim dos tempos; de outro lado, a escatologia

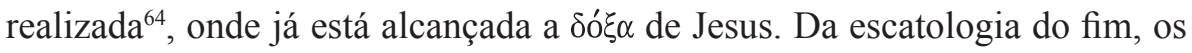
Sinóticos são os representantes mais significativos; a escatologia realizada é representada, no Novo Testamento, pela visão escatológica de Paulo e de João.

A pregação mitológica, segundo Bultmann, foi conservada e continuada em sua forma mitológica pela comunidade cristã primitiva; o que vemos nos Sinóticos. Muito cedo, porém, começou o processo de demitologização,

${ }^{62}$ Cf. BROWN, R.E. L'église héritée des Apôtres, pp. 158-64.

${ }^{63}$ SANCHEZ MIELGO, G. Imágenes eclesiales en el Evangelio joánico, p. 537. Brown chama a eclesiologia joanina de "eclesiologia de adesão" (L'Église héritée des Apôtres, p. 141).

${ }^{64}$ DODD, C.H. La prédication Apostolique, p. 92, prefere chamar de "escatologia sublimada". 
parcialmente com Paulo e definitivamente com João. Para Paulo, quem está em Cristo já é nova criatura (cf. 2Cor 5,17), e para João quem crê em Cristo tem a vida eterna (cf. Jo 5,24). Há um processo de superação da visão da escatologia a partir de um drama cósmico, aguardado para um futuro cronológico.

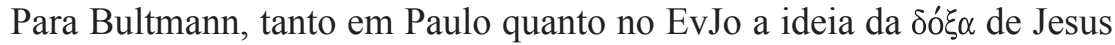
está historicizada (Jo 1,14; 2 Cor 3,7ss), e em ambos a nova vida aparece sob a máscara da morte (Jo $11,25 \mathrm{~s} ; 16,33 ; 2$ Cor $4,17 \mathrm{~s}$ ), sendo que o "novo éon irrompeu no evento Jesus Cristo" 65 ."Para ambos o evento escatológico é compreendido como o que se realiza já no presente, embora João seja o primeiro a levar essa concepção até as últimas consequências"66, "o qual elimina por completo a escatologia apocalíptica"67.

A Igreja é a comunidade escatológica dos santos, que já estão justificados e que vivem porque estão em Cristo; em Cristo que, como segundo Adão, superou a morte e fez brilhar a vida e a imortalidade pelo evangelho ( $\mathrm{Rm} 5,12-14)$. Como

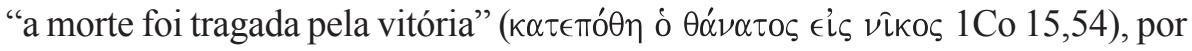
isso Paulo pode dizer que as esperanças e promessas dos profetas se cumpriram com a proclamação do Evangelho: "Eis agora o tempo, sobretudo oportuno (do qual falou Isaias), eis agora o dia da salvação" (2Cor 6,2). O Espírito Santo, que era esperado como a dádiva do tempo da bem-aventurança, já foi concedido; desse modo o futuro é antecipado. ${ }^{68}$

Bultmann, como já foi dito acima, afirma que, depois de Paulo e em continuidade com ele, João demitologizou a escatologia de modo radical. Para João o que constitui o acontecimento escatológico são a vinda e a partida de Jesus. "O julgamento é este: que a luz veio ao mundo, e os seres humanos

${ }^{65}$ BULTMANN, R. A Cristologia do Novo Testamento. In: Crer e Compreender, p. 118. Alhures, afirma: "O evento que, como fato dentro do tempo, transforma todo o mundo - por ser evento crítico - é o envio e a missão de Jesus" (Id. A escatologia do Evangelho de João. In: Crer e Compreender, p. 127).

${ }^{66}$ Id. Teologia do Novo Testamento, p. 437. Esta concepção exigiu que atribuísse algumas passagens que se referem a uma escatologia do fim (Jo 5,28s; 6,39.40.44.54; 12,48) a um "redator eclesiástico" que teria, desse modo, feito com que o evangelho revolucionário se tornasse aceitável no plano eclesiástico. Esta é uma solução com grande agressividade ao texto final, que é submetido a cortes para dele tirar uma teologia supostamente original, sendo que o que interessa é o sentido deste texto que está aí e não "a concepção básica do evangelho" sem os acréscimos (cf. Id. A escatologia do Evangelho de João. In: Crer e Compreender, p. 121, em nota).

${ }^{67}$ Id. Novo Testamento e mitologia. In: Crer e Compreender, p. 28.

${ }^{68}$ Cf. BARRETT, C.K. The Gospel according to John, p. 55. Barrett destaca a novidade de Paulo e do EvJo justamente quanto à ação do Espírito na vida dos cristãos. É o Espírito que realiza a escatologia. Cf. também BULTMANN, R. Jesus Cristo e Mitologia. In: Crer e Compreender, p. 62. 
amaram mais as trevas que a luz; porque as suas obras eram más" (Jo 3,19). "Agora é o momento de ser julgado este mundo; agora o seu príncipe será expulso" (Jo 12,31). Para João a ressurreição de Jesus, Pentecostes e $\pi \alpha \rho o v \sigma i ́ \alpha$ de Jesus são um único acontecimento, e os que creem possuem, já agora, a vida eterna. "Quem nele crê não é julgado; o que não crê já está julgado" (Jo 3,18). "Quem crê no Filho tem a vida eterna; o que, todavia, se mantém rebelde contra o Filho não verá a vida, mas sobre ele permanece a ira de Deus" (Jo 3,36). "Em verdade, em verdade vos digo, que vem a hora, e já chegou, em que os mortos ouvirão a voz do Filho de Deus; e os que a ouvirem viverão" (Jo 5,25). "Eu sou a ressurreição e a vida. Quem crê em mim, ainda que morra viverá; e todo o que vive e crê em mim, não morrerá eternamente" (Jo 11,25-26). Essas passagens, no parecer de Bultmann, atestam claramente que o que se deve esperar não está, cronologicamente, diante dos que creem, mas diante deles como oferta ${ }^{69}$. Paulo e João concebem o ser humano já em um "existir escatologicamente"; mas isto não seria um estado, "algo assumido de uma vez por todas, mas sim algo que se deve comprovar sempre nas situações concretas"

A existência escatológica, porém, não é uma conquista, uma "obra", foi Deus quem fez novo o próprio ser humano: "Se alguém está em Cristo, é nova criatura: as coisas antigas passaram; eis que se fizeram novas!" (2Cor 5,17). Assim diz Paulo. O mesmo afirma, em sua linguagem, João. Ele diz que o conhecimento da verdade de Deus, revelada em Jesus, liberta o ser humano (Jo 8,32), a saber, da escravidão sob o pecado (Jo 8,34). O ser humano é chamado por Jesus da morte para a vida (Jo 5,25$)$, das trevas da cegueira para a luz (Jo 9,29). O crente é alguém que "nasceu de novo" (Jo 3,3ss), obteve uma nova origem ${ }^{71}$.

Segundo Dodd, Paulo elabora um "misticismo crístico"72, no qual o futuro esperado nos alcança pelo dom do Espírito Santo, que é o novo princípio de vida cristã, enquanto que para João a vida eterna já nos é dada pela fé em Jesus. Ambos - Paulo e João - enveredam pelo caminho da escatologia realizada,

${ }^{69}$ Cf. Id. Jesus Cristo e Mitologia. In: Crer e Compreender, p. 63.

${ }^{70}$ BULTMANN, R. Novo Testamento e Mitologia, In Crer e Compreender, p. 28. Nesta mesma página diz: "O juízo universal não é um evento cósmico vindouro, mas o fato de que Jesus veio ao mundo e chamou à fé (Jo 3,19; 9,39; 12,31)".

${ }^{71}$ Cf. Id. Novo Testamento e Mitologia, In Crer e Compreender, p. 37. Assim, Bultmann justifica o processo de demitologização dos Evangelhos, visto que o processo já começou no próprio NT com Paulo e João. Ele admite como motivação desta demitologização da escatologia a apresentação existencial do querigma feito por Paulo e por João.

${ }^{72}$ Cf. DODD, C.H. La prédication Apostololique, p. 90. 
sendo que, para Dodd, como já dissera Bultmann, João é sua "radicalização", chegando, para Dodd a uma "escatologia sublimada"

Brown postula que o processo de ênfase em uma "escatologia realizada" feita pelo EvJo teria sido motivado pela expulsão dos cristãos das sinagogas, foi "a necessidade de enfatizar o que tinham ganhado poder justificar o desenvolvimento de um forte senso joanino de escatologia realizada" ${ }^{\text {"4 }}$.

Barrett admite uma relação teológica da justificação paulina, segundo a qual "não há mais condenação para os que estão em Cristo Jesus" (Oủóév ’’ $\rho \alpha$

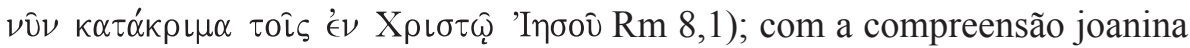

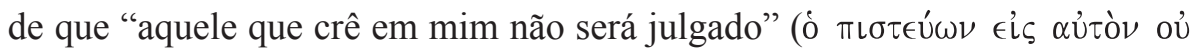

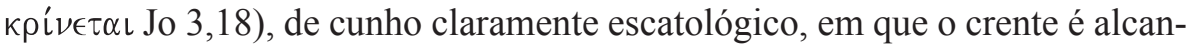
çado pelo $\tau$ t'́ $\lambda \circ \varsigma^{75}$.

Schnackenburg concede que o EvJo tenha reinterpretado a terminologia escatológica tradicional, porém descarta que esteja provado ou mesmo que seja provável que ele tenha descartado a fé comum da Igreja primitiva

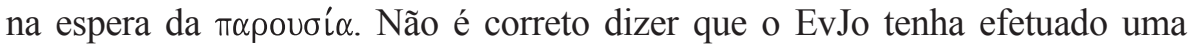
"desescatologização"; o que fez foi destacar o "já" da ação do Filho, a experiência da vida que ele possui é algo presente e accessível ${ }^{76}$. O que Paulo e João fazem é uma valorização do novo que alcançou aquele que está em Cristo (Paulo), que crê (João). Não há porque exorcizar a escatologia do fim, pois ela, embora usando uma terminologia disponível da apocalíptica judaica, resguarda aquela reserva de não cumprimento, que é essencial para a esperança.

Paulo, ao manter os traços da apocalíptica na sua exposição sobre a escatologia, não quis com isso destacar data e circunstâncias, mas "a certeza e a promessa que eles contêm para a situação presente do cristão" 77 . A relação de Paulo com o João quanto à escatologia está na atualização vivencial.

Admitidas as ponderações de Schnackenburg, mas considerando a evidência dos dados de Paulo e de João, acrescido da reflexão teológica, nasce a indagação do lugar que ocupa na vida cristã e no pensar eclesiológico o que já

\footnotetext{
${ }^{73}$ Ibid., p. 92. De qualquer modo não é apresentado, neste ponto, o tipo de relação de Paulo com João, se de dependência criativa, de substrato comum ou de total independência.

${ }^{74}$ BROWN, R.E. A comunidade do discípulo amado, p. 52. Embora esteja por ser demonstrada, esta concepção de Brown consegue uma boa síntese de teologia, história e texto final do evangelho. ${ }^{75}$ Cf. BARRETT, C.K. The Gospel according to John, p. 56. Segundo o autor, há uma correspondência do "estar em Cristo" paulino com o "crer em Cristo" joanino.

${ }^{76} \mathrm{Cf}$. SCHNACKENBURG, R. Église et parousie. In: Le mensage de Jésus et l'interprétation moderne, p. 12. O autor submete a visão de Bultmann a uma análise crítica.

${ }^{77}$ SCHNACKENBURG, R. Église et parousie, p. 32.
} 
aconteceu do extraordinário trazido pela visita de Deus em Jesus Cristo. A autocompreensão deve sempre de novo ser revista a partir da escatologia ${ }^{78}$. Mas o anúncio sempre presente do evento Jesus Cristo abre ao discípulo o espaço do poder ser, do futuro, do estar na vida ${ }^{79}$.

Entre os cristãos das diversas comunidades, que lugar tem ocupado a novidade já verificada na história pelo testemunho dos textos revelados e de pessoas que experimentaram?

Fica patente que ao indicativo segue sempre um imperativo. Este é o ponto de uma síntese existencial da escatologia do fim e a escatologia realizada. Se fosse somente voltada para o fim, enquanto algo que está diante, esvaziaria a novidade da vida cristã; mas se retirasse a perspectiva voltada para o futuro, a tensão da vida cristã perderia seu lugar. "A fé perderia seu sentido, se o crente acreditasse que já está garantido". 80

\section{Conclusão}

Não há em João dependência literária, mono-linear, em relação a Paulo. Do ponto de vista teológico, podemos concluir com Barrett que a teologia joanina pressupõe a existência da paulina. Ou seja, João constrói uma teologia da centralidade do Lógos que pressupõe a desconstrução feita por Paulo da Torah como caminho de salvação. Ademais, os dois corpora testemunham uma teologia com muitos pontos de contato, como é visto ao tratar na perspectiva da teologia bíblico-sistemática.

A presente pesquisa se conclui com a clara convicção que há um viés teológico aberto de relação de textos de corpora diferentes ao interno do NT. Não se há que subestimar os frutos que a exegese poderá produzir ao evidenciar os grandes pilares sobre os quais o NT foi alicerçado. Isso será possível, aproximado textos e colhendo da semântica e da teologia os pontos de encontro.

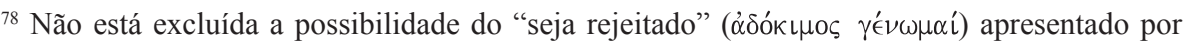
Paulo, em 1Cor 9,27.

${ }^{79}$ Cf. BULTMANN, R. A Escatologia do Evangelho de João. In: Crer e Compreender, p. 129.

${ }^{80}$ Id.. Teologia do Novo Testamento, p. 391.
} 


\section{Referências bibliográficas}

BARRETT, C.K. The Gospel according to John.Introduction with Commentary and Notes on the Greek Text. London: SPCK, 1978 (2a. ed).

BENOIT, P. Paulinisme e Johannisme. NTS 9, n.3, (1963), p. 193-207.

BLANK, J. O Evangelho segundo João. Petrópolis: Vozes, 1988. v. I, II, III, IV. (or. Alemão de 1977).

BOISMARD, M. E.; LAMOUILLE, A. L'Évangile de Jean: Synopse des Quatre Évangiles en Français. Paris: Éditions du Cerf, 1977. v. I, II e III.

BRETON, S. Christianisme: Paul ou Jean? Esprit. n. 2, (2003), p. 66-78.

BROWN, J.K. Creation's Renewal in the Gospel of John. CBQ 72, n.2 (2010), p. 275-290.

BROWN, R. E. A Comunidade do Discípulo Amado. São Paulo: Paulinas, 1981.

. L'église heritée dês Apôtres. Paris: Éditons du Cerf, 1996 (3a. ed).

. The Gospel according to John. New York: Doubleday \& Company, 1970 (vol I e II).

. Johannine Ecclesiology. The Community's Origins. Int 31, n.4 (1977), p. 379-393.

BULTMANN, R. Das Evangelium des Johannes. Göttingen: Vandenhoeck \& Ruprecht, $1952^{12}$. . Jesus. Mythologie et démytologisation, Paris. Du Seuil, 1968.

. Novo Testamento e mitologia. In: Crer e Compreender. São Leopoldo, Sinodal. 1987. p. 13-45. (or. alemão 1941).

. O problema da "Teologia Natural". In: Crer e Compreender. São Leopoldo: Sinodal, 1987, p. 135-149. (or. alemão 1933).

. O problema da demitologização. In: Demitologização. Coletânea de ensaios. São Leopoldo: Sinodal, 1999.

- O que o Jesus histórico significou para a teologia de Paulo. In: Crer e Compreender. São Leopoldo, Sinodal. 1987. p. 81-102. (or. alemão 1929). 
. Teologia do Novo Testamento. São Paulo: Teológica, 2004. (original alemão de 1953).

- A Cristologia do Novo Testamento. In: Crer e Compreender. São Leopoldo, Sinodal. 1987, p. 103-120. (or. alemão 1933).

DODD, C. H. A Interpretação do Quarto Evangelho. São Paulo: Paulinas, 1977. (or. inglês 1968, $8^{\text {a }}$. Ed., $1^{\text {a }}$. 1953). Há outra tradução de 2003 Teológica - Paulus.

. La prédication apostolique et ses développements. Paris: Ed. Universitaires, 1964. (or. inglês de 1936).

FORTNA, R. T. Christology in the Fourth Gospel: Redaction-critical Perspective, NTS 21, n.4, (1975), p. 489-504.

FRIES, H. Démythologisation et vérité théologique. In: Message de Jésus e l'interprétation moderne. Mélanges Karl Rahner. Paris: Édition du Cerf, 1969.

GOURGUES, M. Cinquante ans de recherche johannique. De Bultmann à la narratologie. In: De bien des manières: La recherche biblique aux abords du XXIe. siècle. Paris: Cerf, 1995, p. 229-306.

MILLAS, J.M. A concepcion Paulina de La Fe y La existência Cristina según la interpretacion de Rudolf Bultmann. EstE 65 (1990), p. 193-214.

MÜLLER-FIEBERG, R. Paulusrezeption in der johannesoffenbarung? Auf der Suche nach dem Erbe des apostels im letzten Buch des biblishen Kanons. NTS 55, n.1, p. 83-103, 2009.

REFOUlÉ, F. Cristologie de Bultmann. In: Que dites-vous Du Christ? De Saint Marc à Bonhoeffer, p. 132.

RICOEUR, P. A hermenêutica Bíblica. São Paulo, Loyola, 2006. (or. francês 2000).

SÁNCHEZ MIELGO, G. Imágenes eclesiales en el Evangelio joánico. CiTom 131 (2004), p. 523-544.

SCHNACKENBURG, R. El Evangelio segun San Juan. Salamanca: Herder, 1980 (vol. I, II, III, IV). . Amistad com Jesus. Salamanca, Síguime, 1998. 
. Cristologia do Novo Testamento. In: Misterium salutis. Compêndio de dogmática histórico-salvífica III/2. Edição de Johannes Feiner, Magnus Löhner. Petrópolis: Vozes, 1973.

. Église et parousie. In: Le message de Jésus et l'interprétation modern: Mélanges Karl Rahner. Paris: Cerf, 1969, p. 7 - 39.

. L'uomo nuovo. Centro della comprensione Cristiana del mondo. In: METZ, J.B. et alii. Comprensione Del mondo nella fede. Bologna, Dehoniana, 1969.

. La cristología paulina e la cristología joánica. In: El Evangelio según san Juan, IV, p. 108-125.

. La nature et le mystère de l'Église dans le Nouveau Testament. In: $L a$ Bible et le mistère de l'Église. Paris: Desclée, 1964, p. 7-138.

José Otacio Oliveira Guedes

Doutor em Teologia Bíblica Professor na PUC-Rio Rio de Janeiro/RJ - Brasil E-mail: joseotacio@yahoo.com

Recebido em: 19/05/14 Aprovado em: 30/06/14 